\title{
Age and Gender Differences of Orthostatic Hypertension in Children
}

\author{
C Wen, R Zou, L Wu, Y Xu, P Lin, F Li, C Wang
}

\begin{abstract}
Background: Orthostatic hypotension (OH) is a common orthostatic blood pressure (BP) regulation disorder. Orthostatic hypertension (OHT), on the other hand, is not so common but has relevancy with autonomic neuropathy and diabetes. Orthostatic hypotension is prevalent in females and elderly person. But prevalence of OHT in age and gender is poorly studied. Methods: A retrospective cross-sectional study was conducted. Data collection was from January 2000 to August 2012. Inclusion criteria were patients referred for syncope of unknown origin, headache, dizziness, chest tightness or sighing. Comparisons were made between males and females, and those $<12$ year and those $\geq 12$ years of age. First outcomes included OHT frequency. Secondary outcomes included age and gender differences in head-up tilt test (HUTT) results and its reaction type, the increment of systolic pressure and diastolic pressure at three minutes of HUTT.

Results: Out of a total of 2089 children, OHT was noted in 498 cases. Orthostatic hypertension frequency was higher in males $(25.93 \% \mathrm{vs} 21.63 \%, \mathrm{p}<0.05)$ and those $\geq 12$ years of age $(20.48 \%$ vs $28.05 \%, \mathrm{p}<0.05)$. In OHT children, HUTT positive rate was higher in females $(48.6 \%$ vs $38.1 \%, \mathrm{p}<0.05)$ and those $\geq 12$ years of age $(51.5 \%$ vs $33.2 \%, \mathrm{p}<0.01)$. No significant age and gender differences were noted in systolic and diastolic BP in OHT children within three minutes during HUTT.

Conclusions: Orthostatic hypotension in children was more often seen in males and in those aged $\geq 12$.
\end{abstract}

Keywords: Age, child, gender, head-up tilt table test, orthostatic hypertension

\section{Artralgia Asociada con la Infección del virus de Chikunguña en Jamaicanos Adultos con Posterioridad al Brote}

\author{
C Wen, R Zou, L Wu, Y Xu, P Lin, F Li, C Wang
}

\begin{abstract}
RESUMEN
Antecedentes: La hipotensión ortostática (HO) es un trastorno de la regulación ortostática común de la presión arterial (PA). Por otro lado, la hipertensión ortostática (HTO) no es tan común, pero tiene importancia en relación con la neuropatía y la diabetes autonómicas. La hipotensión ortostática es frecuente en mujeres y personas mayores. Pero la prevalencia de HTO con respecto a edad y género no ha sido muy estudiada.
\end{abstract}

From: Department of Pediatrics, the Second Xiangya Hospital of Central South University, China.
Correspondence: Dr W Cheng, Department of Pediatrics, the Second Xiangya Hospital of Central South University, Changsha city, 410011, China. Email: wxy440501@163.com 
Métodos: Se realizó un estudio retrospectivo de corte transversal. La recogida de datos se realizó de enero de 2000 hasta agosto de 2012. Los criterios de inclusión fueron los pacientes remitidos por sincope de origen desconocido, dolor de cabeza, mareos, opresión en el pecho o suspiros. Se realizaron comparaciones entre varones y hembras, y aquellos de $<12$ y $\geq 12$ años de edad. Los primeros resultados incluyeron la frecuencia de HTO. Los resultados secundarios incluyeron diferencias de edad y de género en los resultados de la prueba de inclinación (PI) y sus tipos de reacción, el incremento de la presión sistólica y la presión diastólica a los tres minutos de PI.

Resultados: De un total de 2089 niños, se observó HTO en 498 casos. La frecuencia de hipertensión ortostática fue mayor en los varones $(25.93 \%$ vs $21.63 \%, p<0.05)$ y aquellos con $\geq 12$ años de edad (20.48\% vs $28.05 \%$, p < 0.05). En niños con HTO, la tasa de PI positivos fue mayor en las hembras (48.6\% vs $38.1 \%, \mathrm{p}<0.05)$ y en aquellos con $\geq 12$ años de edad $(51.5 \%$ vs $33.2 \%, \mathrm{p}<0.01)$. No se observó ningún tipo de depresión cardiaca. El tipo mixto fue visto más a menudo en hembras $(25.2 \% \mathrm{vs} 13.2 \%, \mathrm{p}<0.05)$. No se observó ninguna diferencia significativa de edad y género en la PA sistólica y diastólica en niños con HTO en el plazo de tres minutos durante la PI.

Conclusiones: La hipotensión ortostática en niños fue vista más a menudo en varones y en aquellos de edad $\geq 12$.

Palabras clave: Edad, niño, sexo, prueba de inclinación, hipertensión ortostática

\section{West Indian Med J 2017; 66 (6): 584}

\section{INTRODUCTION}

Orthostatic hypotension $(\mathrm{OH})$ is a common phenomenon in clinic when a person changes the body position from supine to upright. It is well-studied and recognized as an independent predictor of cardiovascular disease and of all-cause mortality (1). Orthostatic hypertension (OHT) is also a manifestation of abnormal postural blood pressure $(\mathrm{BP})$ regulation, which refers to increase in $\mathrm{BP}$ when a person assumes an upright position from supine position. However, OHT is not given enough attention clinically. Therefore, there is as yet no unified diagnosis criterion for OHT. In many studies, an increase in systolic blood pressure (SBP) of $\geq 20 \mathrm{mmHg}$ and (or) diastolic pressure (DBP) of $\geq 10 \mathrm{mmHg}$ within three minutes after body position changed from spine to upright is regarded as the diagnostic criteria of OHT (2).

\section{SUBJECTS AND METHODS}

\section{Design}

We conducted a retrospective cross-sectional study at both in-patient and outpatient Departments of the Children's section of the Second Xiangya Hospital of Central South University, China. Data collection was from Jan 2000 to August 2012.

\section{Study population and methods}

Inclusion criteria were patients, age $<18$ years, referred for syncope of unknown origin, headache, dizziness, chest tightness or sighing and who underwent head-up tilt test (HUTT). Exclusion criteria were patients in whom physical diseases, such as arrhythmia, epilepsy, myocarditis, etc, were detected by medical record review, physical examination, 12-lead (ECG) electrocardiogram, Holter ECG, echocardiogram, electroencephalography, brain computerized tomography or magnetic resonance imaging, etc. This project was approved by Ethics Committee of the second Xiangya Hospital.

Head-up tilt test, as a noninvasive test, included two parts, which were baseline HUTT and sublingual nitroglycerin HUTT. It was performed after gaining the informed consent from all the subjects and their guardians. How HUTT was processed and the criteria for positive HUTT and reaction type was specifically described in former papers $(3,4)$.

Orthostatic hypertension was noted by reviewing the record of HUTT, which diagnostic criteria included an increase in SBP of $\geq 20 \mathrm{mmHg}$ and (or) DBP of $\geq 10$ $\mathrm{mmHg}$ within three minutes of HUTT (2). 


\section{Data analysis}

Comparisons were made between males and females, and those $<12$ and those $\geq 12$ years of age. First outcomes included OHT frequency. Secondary outcomes included age and gender differences in HUTT results and its reaction type, the increment of SBP and DBP at three minutes of HUTT. The Statistical Package for the Social Sciences -17 (SPSS 17.0) software was used to do the statistical analysis, $t$-tests were used for comparisons of measurement data between groups and $\chi^{2}$ analysis or Fisher exact probability were used to compare numeration data. A $p<0.05$ was considered statistically significant.

\section{RESULTS}

Two thousand and eighty-nine children, whose age ranged from 2.00 to $17.92(10.79 \pm 2.94)$ years old satisfied the inclusion criteria and beyond the exclusion criteria. Of the 2089 cases, 1072 were males and 1162 were aged $<12$ years. Orthostatic hypertension was noted in $23.84 \%$ (498/2089) cases, of whom 278 were males and 238 were aged $<12$ years. It occurred more often in males than in females $(25.93 \%$ vs $21.63 \%, p<$ $0.05)$. Statistically significant differences noted between $<12$ years group and $\geq 12$ years group $[20.48 \%$ vs $28.05 \%, p<0.01$ ] (Table 1).

In OHT children, HUTT positive rate was higher in females than in males $(48.6 \%$ vs $38.1 \%, p<0.05)$ and higher in those age $\geq 12$ years than those age $<12$ years $(51.5 \%$ vs $33.2 \%, p<0.01)$ [Table 2].
The increment in SBP equaled to SBP at three minutes of HUTT minus baseline SBP, as well as increment in DBP. No statistical differences were noted between those aged $<12$ years and those age $\geq 12$ years. There were no statistical differences between males and females in the $<12$-year group and $\geq 12$-year group (Table 3 ).

\section{DISCUSSION}

Research so far has drawn different conclusions about OHT due to no unified diagnostic standard. Some researchers described OHT as an orthostatic increase in DBP from below 90 to above $90 \mathrm{mmHg}$ (5). In most of the studies, OHT was defined as elevation of SBP by at least $20 \mathrm{mmHg}$ after standing-up from the supine position, while in the others defined as elevation of SBP by at least $10 \mathrm{mmHg}$ even $5 \mathrm{mmHg}$ after standing-up (6-9). In our study, OHT was defined as elevation of SBP by $\geq 20 \mathrm{mmHg}$ and (or) elevation of DBP by $\geq 10 \mathrm{mmHg}$ within three minutes after standing-up during HUTT (2).

Table 1: Age and gender difference in orthostatic hypertension frequency during head-up tilt test [n (\%)]

\begin{tabular}{lcccc}
\hline Age & \multicolumn{2}{c}{ Male } & \multicolumn{2}{c}{ Female } \\
& $\mathbf{n}$ & OHT & $\mathbf{n}$ & OHT \\
\hline$<12$ years & 623 & $137(21.99)$ & 539 & $101(18.74)$ \\
$\geq 12$ years & 449 & $141(31.41)$ & 478 & $119(24.90)$ \\
total & 1072 & $278(25.93)$ & 1017 & $220(21.63)$ \\
\hline
\end{tabular}

OHT: Orthostatic hypertension; HUTT: head-up tilt test

Table 2: Age and gender differences of head-up tilt test results among orthostatic hypertension children (n)

\begin{tabular}{llrrrr}
\hline Groups & & \multicolumn{4}{c}{ HUTT } \\
& & Negative & positive & \multicolumn{1}{c}{$\chi^{2}$} & $\boldsymbol{p}$ \\
\hline \multirow{2}{*}{ Gender } & Male & 172 & 106 & 5.53 & $<0.05$ \\
& Female & 113 & 107 & 9 & \\
\multirow{2}{*}{ Age } & $<12$ year & 159 & 79 & 17.084 & $<0.01$ \\
& $\geq 12$ year & 126 & 134 & & \\
\hline
\end{tabular}

Table 3: Age and gender differences in blood pressure increment within three minutes of head-up tilt test in orthostatic hypertension children $(\mathrm{mmHg})$

\begin{tabular}{|c|c|c|c|c|c|c|}
\hline \multirow[t]{2}{*}{ Gender } & \multicolumn{3}{|c|}{$<12$ years $(n=238)$} & \multicolumn{3}{|c|}{$\geq 12$ years $(n=260)$} \\
\hline & $\mathbf{n}$ & $\begin{array}{l}\text { Increment } \\
\text { of SBP }\end{array}$ & $\begin{array}{c}\text { Increment of } \\
\text { DBP }\end{array}$ & $\mathbf{n}$ & $\begin{array}{c}\text { Increment of } \\
\text { SBP }\end{array}$ & $\begin{array}{c}\text { Increment of } \\
\text { DBP }\end{array}$ \\
\hline Male & 137 & $8.22 \pm 7.34$ & $13.07 \pm 5.08$ & 141 & $8.45 \pm 7.00$ & $13.65 \pm 3.65$ \\
\hline Female & 101 & $9.26 \pm 7.04$ & $12.87 \pm 4.19$ & 119 & $7.45 \pm 7.68$ & $13.24 \pm 3.67$ \\
\hline$t$ & & 1.098 & 0.644 & & 1.100 & 0.882 \\
\hline$p$ & & $>0.05$ & $>0.05$ & & $>0.05$ & $>0.05$ \\
\hline
\end{tabular}

SBP: systolic blood pressure; DBP: diastolic blood pressure 
Normally, the BP fluctuates constantly. In healthy population, there are integrated and effective regulation mechanisms that help maintain the BP at relative stable level in the presence of change of either internal or external environment so as to avoid harm induced by great BP fluctuations. The change of body position has the most significant impact on BP. When a healthy person change his posture from supine standing, blood in his lower limbs increase due to gravitation, which results in a temporary reduction of blood volume returned to the heart. At the meantime, slight and temporal BP dropping, especially in SBP, can be detected $(10,11)$.

Carotid sinus and aortic arch baroreceptor increases impulse releasing if BP falls is sensed due to the decrease of returned blood volume. Then the signal is transmitted to solitarius nucleus within the medulla oblongata which increases the activating signal of sympathetic nerves resulting in constriction of arteriole so as to maintain the stability of BP. If the sympathetic nerve system is over-activated, BP increases excessively which results in OHT (12). Thomas et al (7) studied the relationship between positional BP change and the eight-year incidence of hypertension in 2781 young adult, and found that the eight-year incidence of hypertension was higher in patients with OHT than those with little fluctuation of BP after assuming standing position (12.4\% vs 6.8\% $p<0.01$ ), and the eight-year incidence of hypertension was $8.4 \%$ in the in-between $\mathrm{OH}$ group. Adjusted odds ratios for developing hypertension during the follow-up period in those with OHT vs those without postural BP change were as follows: in black men, 2.85 (95\% confidence interval [CI], 1.43, 5.69), in black women, 2.47 (95\% CI, 1.19, 5.11), in white men, 2.17 (95\% CI, 1.00, $4.73)$, and in white women, 4.74 (95\% CI, 1.11, 20.30), indicating that increased sympathetic nervous system reactivity and remodelling of capillary are the risk factors of the hypertension (7).

The differences in OHT incidence reported in the literature might be associated with the different diagnostic criteria applied. The incidence of OHT is significantly higher in patients with elderly borderline hypertension, autonomic neuropathy and diabetes than in the normotensive subjects. Orthostatic hypertension was detected in $4.2 \%$ of healthy pilots (9). Fan et al (13) conducted a cross-sectional study in 4711 hypertensives (aged 40-75 years) in seven communities and they found that the incidence of OHT was $16.3 \%$. Wu et al (14) conducted a population-based study on the prevalence and orthostatic hypotension/hypertension and orthostatic dizziness in 1638 adult cases (aged above 20 years) and found that the prevalence of OHT was $1.1 \%$ with onset above 40 years of age. The study of Fedorowski et al (15) on a total of 700 non-diabetic adults regarding the changes in orthostatic BP, intima-media thickness (IMT) and P-fibrinogen revealed that orthostatic hypotension and OHTN occurred in $5.7 \%$ and $6.4 \%$ study participants. The Atherosclerosis Risk in Communities (ARIC) study included 15792 persons between 45 and 64 years of age at the baseline examination and in this study OHT was found in $2.36 \%$ of the study population (12). In our study, HUTT test on all the subjects with syncope of unknown origin, headache, dizziness, chest tightness or sighing showed that OHT occurred in $23.84 \%$, showing significantly higher incidence than that reported by $\mathrm{Wu}$ et al (14) and this difference might be attributed to the difference in diagnostic criteria applied for OHT and the fact that most of the subjects enrolled had autonomic nervous dysfunction.

Our study showed that OHT in children occurred mainly in males and those age above 12 years. Jarvis et al (16) reported that the mean arterial pressure measured during supine baseline conditions and 70 degree headup tilt positions were significantly lower in 14 healthy women than in 16 healthy men (all $p<0.01$ ), which is in conformity with our finding. Barnett et al (17) measured vasoactive peptide levels in the supine and 60 degree head-up tilt positions in 89 healthy subjects (41 men, 48 women, aged 20 to 83 years) and found that plasma norepinephrine during tilt was lower in women than in men $(p<0.05)$ thus, OHT occurred more in male than in females. Streeten et al (5) found that orthostatism induced increased sympathetic stimulation and significantly higher plasma norepinephrine concentrations in the orthostatic hypertensive subjects than in the normotensive subjects $(p<0.05)$, which might play a direct role in inducing OHT. It has been shown that excessive vascular adrenergic sensitivity in OHT subjects that increase orthostatic pressure response is also the mechanism related to adrenaline release in the development of OHT (9). Our data showed no differences in age and gender with regards to increments in SBP and DBP within three minutes of HUTT, indicating that the sympathetic reaction is independent of age and gender in children after standing-up.

Our findings that OHT occurred more often in females than in males among HUTT positive children and more in $\geq 12$-year age group than in $<12$-year age group might be attributed to the fact that HUTT positive is more often seen in females and in the $\geq 12$-year age group (3). Longin et al (18) analysed the difference of heart rate variability (HRV) between 
55 children with a history of neurocardiogenic syncope (NCS) or presyncopal symptoms and healthy control subjects during the resting position, 60 degree tilt table testing, and active standing, and found that compared with healthy control subjects, children with NCS had autonomic nerve dysfunction, increase of sympathetic nerve tone and decrease of vagal tone. The development of OHT is associated with excessive sympathetic activation, resulting in age and gender differences of OHT among HUTT positive children.

Evidently, OHT is not rare in children. However, there is paucity of study on OHT in children and there are as yet no unified diagnostic criteria for OHT and the diagnostic differs greatly between different studies. Our findings suggest that OHT in children occurs more often in males and in those aged $\geq 12$ years and there are no age or gender differences regarding the increments in SBP and DBP within three minutes of HUTT. These findings are of guiding value in clinical diagnosis and the understanding of OHT in children.

\section{ACKNOWLEDGEMENTS}

This study was supported by the National Sciencetechnology Support Plan Projects of "The $12^{\text {th }}$ Five-year Plan" (2012BAI03B03) and the Hunan Science and Technology Office Funded Project (2012FJ3127).

\section{REFERENCES}

1. Fenech G, Safar M, Blacher J. Orthostatic hypotension: marker of severity and management of antihypertensive treatment. Presse Med 2012; 41: 1116-21.

2. Zhao J, Yang JY, Jin HF, DU JB. Clinical analysis of orthostatic hypertension in children. Chin J Pediatr 2012; 50: 839-842.

3. Wang C, Li W, Wu L, Lin P, Li F, Luo H et al. Clinical characteristics and treatment of 89 patients with head-up tilt table test induced syncope with convulsion. J Cent South Univ (Med Sci) 2013; 38: 70-3.

4. Subspecialty Group of Cardiology, The Society of Pediatrics, Chinese Medical Association; Editorial Board, Chin J Pediatrics. Guidelines for diagnosis of syncope in children. Chin J Pediatr 2009; 47: 99-101.
5. Streeten DH, Auchincloss JH Jr, Anderson GH Jr, Richardson RL, Thomas FD, Miller JW. Orthostatic hypertension. Pathogenetic studies. Hypertension 1985; 7: 196-203.

6. Robertson D. Orthostatic hypertension: the last hemodynamic frontier. Hypertension 2011; 57: 158-9.

7. Thomas RJ, Liu K, Jacobs DR Jr, Bild DE, Kiefe CI, Hulley SB. Positional change in blood pressure and 8-year risk of hypertension: the CARDIA study. Mayo Clin Proc 2003; 78: 951-8.

8. Kario K, Shimada K. Risers and extreme-dippers of nocturnal blood pressure in hypertension: antihypertensive strategy for nocturnal blood pressure. Clin Exp Hypertens 2004; 26: 177-89.

9. Buddineni JP, Chauhan L, Ahsan ST, Whaley-Connell A. An emerging role for understanding orthostatic hypertension in the cardiorenal syndrome. Cardiorenal Med 2011; 1: 113-122.

10. Li J, Wang YJ, Zhang M, Xu ZQ, Gao CY, Fang CQ et al. Vascular risk factors promote conversion from mild cognitive impairment to Alzheimer disease. Neurol 2011; 76: 1485-91.

11. Hoshide S, Parati G, Matsui Y, Shibazaki S, Eguchi K, Kario K. Orthostatic hypertension: home blood pressure monitoring for detection and assessment of treatment with doxazosin. Hypertens Res 2012; 35: 100-6.

12. Yatsuya H, Folsom AR, Alonso A, Gottesman RF, Rose KM; ARIC Study Investigators. Postural changes in blood pressure and incidence of ischemic stroke subtypes: the ARIC study. Hypertension 2011; 57: 167-73.

13. Fan XH, Wang Y, Sun K, Zhang W, Wang H, Wu H et al. Disorders of orthostatic blood pressure response are associated with cardiovascular disease and target organ damage in hypertensive patients. Am J Hypertens 2010; 23: 829-37.

14. Wu JS, Yang YC, Lu FH, Wu CH, Chang CJ. Population-based study on the prevalence and correlates of orthostatic hypotension/hypertension and orthostatic dizziness. Hypertens Res 2008; 31: 897-904.

15. Fedorowski A, Ostling G, Persson M, Struck J, Engström G, Nilsson PM et al. Orthostatic blood pressure response, carotid intima-media thickness, and plasma fibrinogen in older non-diabetic adults. J Hpertens 2012; 30: 522-9.

16. Jarvis SS, Florian JP, Curren MJ, Pawelczyk JA. Sex differences in vasoconstrictor reserve during 70 deg head-up tilt. Exp Physiol 2010; 95: 184-93.

17. Barnett SR, Morin RJ, Kiely DK, Gagnon M, Azhar G, Knight EL et al. Effects of age and gender on autonomic control of blood pressure dynamics. Hypertension 1999; 33: 1195-1200.

18. Longin E, Reinhard J, von Buch C, Gerstner T, Lenz T, König S. Autonomic function in children and adolescents with neurocardiogenic syncope. Pediatr Cardiol 2008; 29: 763-70. 